BMJ Open

Sport \&

Exercise

Medicine

\section{Epidemiology of injuries in the Spanish national futsal male team: a five-season retrospective study}

To cite: Martinez-Riaza L, Herrero-Gonzalez H, LopezAlcorocho JM, et al. Epidemiology of injuries in the Spanish national futsal male team: a five-season retrospective study. BMJ Open Sport Exerc Med 2017;2:e000180.

doi:10.1136/bmjsem-2016000180

- Prepublication history is available. To view please visit the journal (http://dx.doi.org/ 10.1136/bmjsem-2016000180).

Accepted 31 January 2017

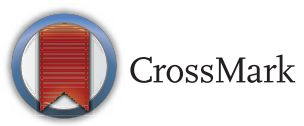

${ }^{1}$ Servicio Médico Real Federación Española de Futbol, Madrid, Spain ${ }^{2}$ Unidad de Investigación Biomédica, Clínica CEMTRO, Madrid, Spain

${ }^{3}$ Servicio de Medicina y Traumatología del Deporte, Clínica CEMTRO, Madrid, Spain

${ }^{4}$ Cátedra de Traumatología del Deporte, Universidad Católica de Murcia, Murcia, Spain

Correspondence to Dr Juan M Lopez-Alcorocho; jm.lopez@amplicel.com

\section{ABSTRACT}

Background: Futsal started being played in 1930 and the number of futsal players has increased all over the world ever since. Nonetheless, despite the fact that Spain is one of the most relevant national teams worldwide, information on the incidence of injuries and their anthropometric characteristics is sparse in this country.

Aim: To analyse medical assistance provided to players in their prematch concentration camps with the Spanish national team over five seasons, from 20102011 to $2014-2015$, and also to collect data regarding anthropometric characteristics.

Materials and methods: This is a retrospective and detailed study of injuries players suffered over these five seasons. All variables were registered on an Excel spreadsheet and later analysed statistically.

Results: 411 injuries were studied in total. The dominant somatotype was mesomorph and the injured pivots were both the most endomorphic and the most mesomorphic. The most injured body structure was the hamstring muscles, occurring due to training and intrinsic mechanisms, where fatigue was the most frequent diagnosis. Only a few complementary examinations were carried out and prematch withdrawal was rare.

Discussion: The skinfold test total sum was lower than that of the Spanish 11-a-side players or than that in the lower category futsal Spanish players. In various research studies analysing exclusively injuries occurring in matches, the most frequent injury is ligament injury by extrinsic mechanism. The body mass index was not a useful parameter when assessing players' appropriate weight. Most injuries occurred in training sessions, mostly by intrinsic mechanism; the highest percentage of traumatic injuries occurred in official matches.

\section{INTRODUCTION}

Futsal is a sport of growing popularity, with a higher injury risk than the 11-a-side football. ${ }^{1}$ Such a difference is credited to the game's nature, which includes continued bouts of intensive physical activity, highspeed execution, smaller pitch dimensions and a harder playing surface.

\section{Key messages}

What are the new findings?

The importance of this work values medical attention during competition and in concentrations without competition also. Knowing the epidemiology of medical care provided to football players depending on the position and the stage of concentration or competition can improve prevention programmes

How might it impact on clinical practice in the near future?

The repercussion in the practical clinic is that once known epidemiology medical attention to footballers allows planning a specific job per position and sportsman to reduce incidences of medical care provided, allowing a more physical preparation Adjusted and the implementation of prevention plans

It was Professor Juan Carlos Ceriani who first established futsal's rules in Montevideo, Uruguay, back in 1930 using certain rules from water polo, basketball, handball and soccer, initially referring to it as indoor hall football' so that football could be played in indoor arenas.

Futsal is a sport played by two five-player teams within the limits of an adapted handball court. A futsal match comprise two $20 \mathrm{~min}$ halves of actual playing time. Each team has a 1 min time out, which may be requested when the team has ball possession.

'Injury' may mean different concepts depending on the study in which it is used: some refer to 'injury' as the instance in which an athlete requires hospital admission, ${ }^{2}$ whereas other authors do not consider an event to be an injury unless the player misses out on a training session or a match. $^{34}$

We have considered any complaint on the players' side that may have required 
medical assistance as an injury, irrespective of whether it caused the player to drop out of the team or not, either for training or competition. Injury was thus considered as such an event which may have needed any kind of medical intervention.

Our aim was twofold: first was to study every single medical assistance action provided to players in the Spanish national futsal male team over five seasons, and the second was to register anthropometric values for these injured players.

\section{MATERIALS AND METHODS}

It is a retrospective study about medical assistance provided to players summoned to the male national team from season 2010-2011 to season 2014-2015.

Physical and anthropometric values were collected following the International Society for Advanced Kinanthropometrys and GREK's regulations while also indicating each player's playing position.

Standard certified material was used for kinanthropometry procedures: weight, skinfold callipers, bicondylar bone calibrator and a non-extensible, flexible, metal tape measure.

The present study includes all injuries suffered by players throughout the forementioned time period. Any unrelated pathology to the musculoskeletal system was not included, and neither was any preventive physiotherapeutic assistance provided without clinical signs of injury.

The analysed variables were classified into three categories:

1. Players' anthropometric data: height; weight, body mass index (BMI) (weight/height) and sum total for six skinfold measures (triceps, subscapular, supraspinal, abdominal, anterior thigh and medial calf) as assessed by adiposity index. ${ }^{5} 6$ Heath and Carter's $\operatorname{method}^{7} 8$ was used to calculate the somatotype component (endomorph, mesomorph, ectomorph). Each of these components was considered to be low if below 2.5, average if between 2.5 and 5, high if between 5 and 7 , and very high if its value was over $7 .^{6}$

2. Technical data: lower limb dominance; players' playing position (keeper, lastman, winger, pivot and wing-pivot).

3. Injury-related data:

- Side of injured limb.

- Aetiology. We consider the possibility of the injury being extrinsic (external causes) or intrinsic (internal causes).

- Injured structure within the musculoskeletal system, whether it is muscle, muscle-tendon union, tendon, bone, bone-tendon union (enthesis), cartilage, ligament, muscle fascia or intra-articular injury.

- Anatomical site of injury.

- Diagnosis. The following diagnoses were included under this heading:
- Residual pain: Discomfort due to lesions appearing prior to the national team call that needed sporadic treatment.

- Muscle overload: Considered as type 1A under the new consensus classification for muscle lesions, ${ }^{9}$ showing to have no anatomical injury but muscle is painful and slightly tight when manually explored, and tend to be due to an overexertion.

- Muscle contraction: Similar case to muscle overload, only with a higher degree of muscle tightness.

- Elongation: Presence of localised and acute pain under fingertip pressure, but no structural changes on images, only oedema.

- Muscle-fibre tear: Corresponds to stage 3 of the new muscle lesion classification, ${ }^{9}$ observable oedema and haemorrhage under MRI.

- Contusion: Referring to any type of injury due to an external trauma, independent of the affected structure.

- Sprain or ligament injury.

- Tendinopathy: Makes reference to tendon damage, whatever its aetiology.

- Intra-articular lesion.

- Fasciitis or other injuries originating at the muscle fascia.

- Time of injury. For this variable, we distinguish three possibilities: prior to the call, base camp training or during an international match.

- Additional explorations performed for the diagnosis: echographies and/or MRI.

- Applied treatment.

- Camp leave due to injury.

\section{Statistical analysis}

All mentioned variables were registered using a spreadsheet for statistical analysis. Data were analysed using IBM's SPSS Statistics, V.22.0.0. Quantitative variables were expressed using the mean and/or median as a measure of central tendency. Dispersion in these variables was expressed as typical deviation and/or maximum and minimum values. Normality was studied using the Kolmogorov-Smirnoff test. Qualitative variables were expressed as absolute frequency and percentage.

Quantitative variables were contrasted using the Kruskal-Wallis test for independent samples. Qualitative variables were analysed using contingency tables and their statistical significance using Pearson's $\chi^{2}$ test.

All hypothesis contrasts performed were bilateral, taking a value of $p<0.05$ as statistically significant.

\section{RESULTS}

During the specified period, there was a total of 27 national team calls. Between 12 and 15 players were called each time, with a total of 349 players being called up over the five seasons. The players' average age was $27.48 \pm 3.98$ years, and the mean weight and 
Figure 1 Number of assistances according to the position.

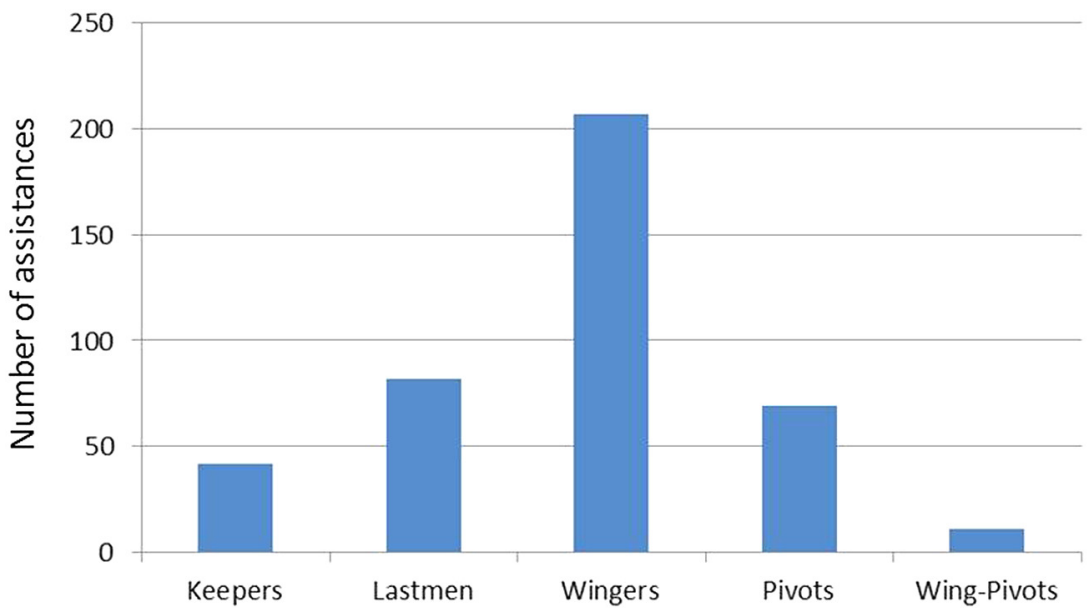

height were $75.19 \pm 7.21 \mathrm{~kg}$ and $178.91 \pm 4.97 \mathrm{~cm}$, respectively. Medical assistance has been provided in 411 cases due to injury to 33 players, resulting in an injury rate of 12.4 lesions/player. With regard to the playing position, of all 411 assistance actions provided, $42(10.2 \%)$ were to keepers, 82 (20\%) to lastmen, 207 (50.4\%) to wingers, $69(16.8 \%)$ to pivots and $11(2.7 \%)$ to wing-pivots (figure 1). Regarding lower limb dominance, $66.7 \%$ (233 players) of all cases showed to be dominant on their right side and 33.3\% (116 players) on their left side.

Mesomorph was the dominant somatotype, as the muscular component showed to be predominant over that of fatty or lean. BMI was 23.47 and the skinfold sum total was 46.71 (table 1):

When relating the BMI with a direct score for adiposity (skinfold sum), we obtained a statistically significant correlation $(\mathrm{r}=0.509 ; \mathrm{p}<0.001$; Pearson's correlation test).

The somatotype analysis measured by the mean of the sum of skinfolds by playing position showed there were statistically significant differences among the different positions ( $p<0.001$; Kruskal-Wallis test) (table 2).

Thus, the highest scores for endomorphy corresponded to pivots and keepers and the lowest scores to wing-pivots. The highest values for muscular component (mesomorphy) corresponded to pivots and the lowest to wing-pivots, with scores for other three positions being similar. Wing-pivots turned out to be the leanest (ectomorphy) and pivots the least lean.

Table 1 Kinanthropometric characteristics

\begin{tabular}{lc}
\hline Body mass index & $23.47 \pm 1.83$ \\
\hline Skinfold sum total & $46.71 \pm 8.23$ \\
Endomorphy & $1.98 \pm 0.43$ \\
Mesomorphy & $5.09 \pm 1.03$ \\
Ectomorphy & $2.14 \pm 0.89$ \\
\hline
\end{tabular}

Of the assistances, $31.1 \%(128)$ were to the right lower limb, 29\% (119) were to the left, $24.6 \%$ (101) were to both lower limbs, and $15.3 \%$ (63 cases) were to other body parts (figure 2). According to their aetiology, most lesions were caused by an intrinsic mechanism (67.2\%), 30.2\% were extrinsic or traumatic, and $2.7 \%$ were of unknown origin.

There were statistically significant differences among aetiologies for different playing positions $(p=0.006$; Pearson's $\chi^{2}$ ) (table 3). Clearly noticeable is the high incidence of intrinsic mechanisms in wings, pivots and wing-pivots, whereas keepers and lastmen suffered injuries due to both intrinsic and extrinsic causes (table 3).

The most commonly injured structure was the muscles $(57.7 \%)$, in contrast to entheses $(0.7 \%)$. Of the injuries occurring at the muscle-tendon union and at the fascia, $100 \%$ were caused by intrinsic mechanisms, just as most muscle injuries were (over 88\%), differences which may be considered statistically significant. In $43.3 \%$ of the cases, lesions were localised in the thigh, followed by the leg $(12.6 \%)$, knee $(10 \%)$, back $(9.7 \%)$, ankle $(6.15 \%)$ and foot $(5.8 \%)$. Most assistance cases $(52.6 \%)$ were due to muscle overload and $14.4 \%$ were due to residual pain.

Injuries by overload in pivots and wing-pivots were more frequent (table 4). Wing-pivots suffered from contractures the most, whereas players assisted mostly for injuries appearing prior to being called up and leaving residual pain behind were keepers, with

Table 2 Skinfold sum by playing position

\begin{tabular}{lc}
\hline Keeper & $51.64 \pm 11.44$ \\
\hline Lastman & $47.38 \pm 6.67$ \\
Wing & $44.06 \pm 7.03$ \\
Pivot & $52.08 \pm 5.61$ \\
Wing-pivot & $39.17 \pm 11.76$ \\
\hline
\end{tabular}




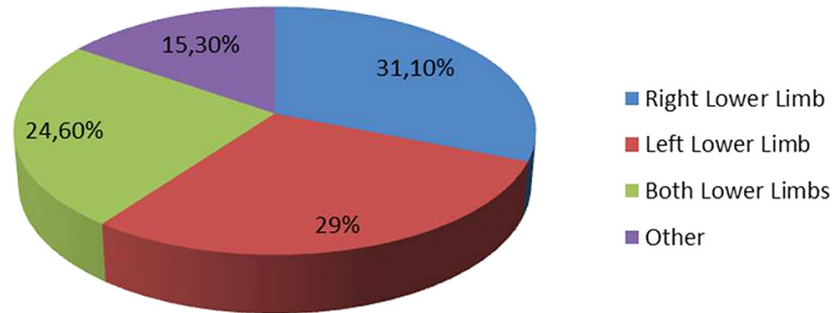

Figure 2 Percentage of patients injured in each body area.

differences being statistically significant $(p=0.033$; Pearson's $\chi^{2}$ test) (table 4 ).

Most injuries (47\%) occurred during base camp training sessions and $31.4 \%$ in international matches. Almost all cases $(96.6 \%)$ were clinically diagnosed with no further tests necessary. A high percentage of cases $(63 \%)$ needed physiotherapy treatment and 2.2\% needed none. Only eight players $(1.9 \%)$ were obliged to leave base camp.

\section{Discussion}

The skinfold sum total scores were slightly lower and less disperse than those found in the 11-a-side male national football team ${ }^{10}(50.2+12.36)$ and in professional football players of the top three Spanish national leagues. ${ }^{11}$

When compared, our values have shown to be notably lower than those for the U-21 national male team obtained at the regional headquarters for sports medicine in Castilla and León $(46.71+8.23$ vs 70.8 +25.1 and $65.15+23.73$, respectively).

When comparing skinfold sum total scores by playing positions, as observed in other studies, ${ }^{12}$ there are statistically significant differences, with keepers showing higher scores than lastmen (table 2).

With regard to somatotype in futsal playing positions, the highest scores for endomorphs and mesomorphs were found in pivots, whereas in other studies ${ }^{12}$ keepers showed the highest scores.

Our study population showed to have a markedly different somatotype compared with U-19s, who also practised this sport and had a much higher endomorphic (fat) component $(2.80+1.05$ vs 1.98$)$ and a much lower mesomorphy (muscle) component $(4.23+1.15$ vs $5.09+1.03)$. Our population also showed a lower endomorphy (fat) component than that reported in another study, while scores for muscle component were very similar.

When comparing the Spanish male futsal player somatotype with that of other countries, we found Colombian players to have a markedly higher fat component $(3.1+1.03)$, even higher than that of Spanish U-21s, whereas their muscular (mesomorphic) and ectomorphic components were very similar. ${ }^{13}$ When studying somatotype values in relation to futsal's different playing positions, our study found pivots to have the highest endomorphic and mesomorphic values, whereas in other papers ${ }^{14}$ these values where highest in keepers.

The BMI values for our population have been similar to those found in Iranian players. ${ }^{15}$

We agree with other authors who conclude that BMI values are not useful when assessing players' body composition as they cannot distinguish whether body weight increases are due to an increase in muscle or fat content. ${ }^{16-18}$ Other authors believe this BMI may be distorted due to the proportionality of sitting height and leg length so that relatively long legs would reduce BMI scores. ${ }^{19}$

Our study has shown that right-footed players suffer ipsilateral injuries more frequently than left-footed players, whose injuries occur more frequently on the contralateral side. These results are in contrast to those of other authors. Serrano et $a l^{20}$ found no significant differences between these two variables.

On a different matter, we have found no statistically significant differences between lesion diagnosis and laterality. Other studies ${ }^{21}$ specifically assessing ankle sprains do find a correlation between injury and contralateral dominance, justifying so as the dominant limb is used most frequently when dribbling, whereas the non-dominant is used mostly for support. This fact justifies, according to their authors, the fact that both feet are trained in training sessions with a football. The highest frequency of ankle sprains in the non-dominant leg was also found by Ekstrand and Gillquist ${ }^{22}$ to appear in football players.

Abate $e t a l^{23}$ in their study about the prevalence of patellar and Achilles tendinopathies in futsal also found a stronger prevalence for the non-dominant leg, justifying it by the forementioned reason as well.

Most lesions (67.2\%) show an intrinsic aetiology, coinciding almost totally with those values found for

Table 3 Lesion aetiology by playing position

\begin{tabular}{lccccc}
\hline & \multicolumn{5}{c}{ Position } \\
\cline { 2 - 6 } Aetiology & Keeper $(\mathbf{n = 4 2})$ & Lastman $(\mathbf{n}=\mathbf{8 2})$ & Wing $(\mathbf{n = 2 0 7 )}$ & Pivot $(\mathbf{n}=69)$ & Wing-Pivot $(\mathbf{n = 1 1 )}$ \\
\hline Unknown & $2(4.8 \%)$ & $1(1.2 \%)$ & $7(3.4 \%)$ & $1(1.4 \%)$ & $0(0.0 \%)$ \\
Extrinsic & $19(45.2 \%)$ & $36(43.9 \%)$ & $54(26.1 \%)$ & $12(17.4 \%)$ & $3(27.3 \%)$ \\
Intrinsic & $21(50.0 \%)$ & $45(54.9 \%)$ & $146(70.5 \%)$ & $56(81.2 \%)$ & $8(72.7 \%)$ \\
\hline
\end{tabular}


Table 4 Lesion site by playing position

\begin{tabular}{|c|c|c|c|c|c|}
\hline \multirow[b]{2}{*}{ Site } & \multicolumn{5}{|c|}{ Position } \\
\hline & Keeper $(n=42)$ & Lastman (n=82) & Wing $(n=207)$ & Pivot $(n=69)$ & Wing-Pivot $(n=11)$ \\
\hline Other & 2 & 4 & 1 & 0 & 0 \\
\hline Residual pain & 9 & 13 & 29 & 8 & 0 \\
\hline Overload & 16 & 30 & 118 & 45 & 7 \\
\hline Contracture & 0 & 4 & 4 & 1 & 2 \\
\hline Elongation & 1 & 0 & 4 & 1 & 0 \\
\hline Muscle-fibre tear & 0 & 2 & 3 & 2 & 0 \\
\hline Tendinopathy & 4 & 3 & 6 & 1 & 0 \\
\hline Sprain & 2 & 10 & 13 & 3 & 1 \\
\hline Intra-articular lesion & 2 & 1 & 3 & 2 & 0 \\
\hline Fasciitis & 0 & 0 & 2 & 0 & 0 \\
\hline Contusion & 6 & 15 & 24 & 6 & 1 \\
\hline
\end{tabular}

the Iranian national team, ${ }^{15}$ as well as with another Portuguese study ${ }^{23}$ and some others too, ${ }^{1}{ }^{19}{ }^{24-26}$ on the fact that most extrinsic or traumatic lesions occurred during official matches. Such a fact had already been proven by Hootman et $a l^{27}$ after analysing 15 team sports practised in the USA between 1998 and 2004.

In our work, most lesions have occurred in the thigh (ischiocrural muscles), coinciding with the values for lesions found at the U20s championship in Brazil. ${ }^{26}$ Nevertheless, in studies carried out at three different Futsal World Cup Championships (2000, 2004 and 2008), ${ }^{25}$ it was the knee followed by the thigh area that suffer most lesions, although in these cases data for official matches were collected, leaving aside training sessions. A study carried out with Portuguese players of varied levels also produced the same findings, with the knee as the most injured site. ${ }^{20}$

In a study carried out in several of Iran's national teams between March 2011 and June 2012 ${ }^{15}$, lesions appeared more frequently in the ankle, followed by the knee, and the total number of injuries increased as the level of players studied decreased.

When it comes to relating the injured site with the lesion aetiology, our findings agree with those of other studies $^{20}$ in that most muscle tendon injuries were caused by an intrinsic mechanism, whereas articular and bone injuries appeared due to extrinsic factors.

Over $50 \%$ of diagnosed cases were muscle overloads, a fact that Junge and Dvorak ${ }^{25}$ justify based on the numerous sprints that also include direction changes performed while practising futsal.

Our study findings show to be in contrast with other works that show that sprains, ${ }^{14}$ mainly in the ankle, or contusions ${ }^{1212225}$ were the most common injuries.
Some studies carried out in the 11-a-side football have established a correlation between different lesions and the playing position, ${ }^{28}$ correlations also found by other authors when referring to keepers. ${ }^{20}$ Other studies have not found such correlations among the different playing positions in futsal. ${ }^{29}$

In reference to the injury diagnosis and the time of appearance of the lesion, we have found statistically significant differences so that injuries by overload occurred during training sessions, whereas contusions were more frequent during matches. Serrano $e t a l^{20}$ in their study with Portuguese futsal players, found-in contrast to our findings - a higher incidence of sprains and contractures during training sessions, whereas the most common injury during matches was muscle-fibre tear.

In summary, the somatotype values for those players who most frequently received medical assistance was mesomorph dominant (1.98 - 5.09 - 2.14). Pivots showed both the highest fat and muscle content of all players. BMI was not found to be useful when assessing players' body composition. Right-footed players suffered ipsilateral injuries slightly more frequently, whereas left-footed players suffered contralateral and two-sided injuries slightly more frequently. Most extrinsic injuries (by external traumatism) took place during official matches. The muscles showed to be the most frequently injured structure, with nearly half of all injuries involving them (43.3\%); the thigh was the most commonly injured site, followed by the leg (12.6\%), knee (10\%), back (9.7\%), ankle (6.15\%) and foot (5.8\%). Over $50 \%$ of diagnoses were muscle overloads. Almost all injuries took place during training sessions, and in most cases (96.6\%) diagnoses were issued after clinical assessment, with no further tests necessary. 
Acknowledgements The authors acknowledge Mario Wensell for his precise translation.

Contributors LM-R and HH-G conducted the study; JML-A performed the analysis of the results and wrote the paper; PG-G collected the results and reviewed the paper; TFF-J designed the study and wrote the paper.

Competing interests None declared.

Provenance and peer review Not commissioned; externally peer reviewed.

Open Access This is an Open Access article distributed in accordance with the Creative Commons Attribution Non Commercial (CC BY-NC 4.0) license, which permits others to distribute, remix, adapt, build upon this work noncommercially, and license their derivative works on different terms, provided the original work is properly cited and the use is non-commercial. See: http:// creativecommons.org/licenses/by-nc/4.0/

(C) Article author(s) (or their employer(s) unless otherwise stated in the text of the article) 2017. All rights reserved. No commercial use is permitted unless otherwise expressly granted.

\section{REFERENCES}

1. A. Hamid MS, Jaafar Z, Mohd Ali AS. Incidence and characteristics of injuries during the 2010 FELDA/FAM National Futsal League in Malaysia. PLOS ONE 2014;9:4:e95158.

2. Hoy K, Lindbd BE, Terkelsen $\mathrm{CJ}$, et al. A prospective epidemiologic and socioeconomic study. Am J Sports Med 1992;20:318-22.

3. Ekstrand J, Editorial KJ. The risk for injury in football. There is a need for a consensus about definition of the injury and the design of studies. Scand J Med Sci Sports 2003;13:147-9.

4. Fuller CW, Ekstrand J, Junge A, et al. Consensus statement on injury definitions and data collection procedures in studies of football (soccer) injuries. Br J Sports Med 2006;40:193-201.

5. Porta J, Galiano D, Tejedo A, et al. Valoración de la composición corporal. Utopías y realidades. In: Esparza F, ed. Manual de cineantropometrÚa. Navarra, Spain: GREC, 1993:113-70.

6. Norton K. Estimación antropométrica de la grasa o adiposidad corporal. In: Norton K, Ed OT, eds. Antropométrica. Rosario: Biosystem, 2000:157-84.

7. Esparza F, Alvero JR. Somatotipo In. Esparza F, ed. Manual de cineantropometrúa. Navarra: GREC, 1993:67-93.

8. Carter L. Somatotipo. In: Norton K, Olds T, eds. Antropométrica. Rosario: Biosystem, 2000:133-55.

9. Mueller-Wohlfahrt HW, Haensel L, Mithoefer K, et al. Terminology and classification of muscle injuries in sport: the munich consensus statement. Br J Sports Med 2013;47:342-50.

10. Casajús JA, Aragonés MT. Estudio morfológico del futbolista de alto nivel composición corporal y somatotipo (Parte I). Arch Med Dep 1991;8:147-51.
11. Casajús JA, Aragonés MT. Estudio cineantropométrico del futbolista profesional español. Arch Med Dep 1997;14:177-84.

12. Canda A. Valores cineantropométricos de referencia In. Esparza $F$, ed. Manual de cineantropometrúa. Navarra: GREC, 1993:171-214.

13. Linares $H$, Jaime $H$, Mora $N$. Perfil cineantropométrico del jugador profesional colombiano de fútbol de salón. Marzo 2013. http: //www. edu-fisica.com

14. De Moura NR, Borges L, Santos VC, et al. Muscle lesions and inflammation in futsal players according to their tactical positions. $J$ Strength Cond Res 2012;27:2616-8.

15. Angoorani $\mathrm{H}$, Haratian $\mathrm{Z}$, Mazaherinzhad $\mathrm{A}$, et al. Injuries in Iran futsal national teams: a comparative study of incidence and characteristics. Asian J Sports Med 2014;5:e23070.

16. Kweitel S. IMC: herramienta poco útil para determinar el peso ideal de un deportista. Rev Int Med Cienc Act FÚs Deporte 2007;7:274-89.

17. Fernández Vieitez JA. Índices de relación peso-talla como indicadores de masa muscular en el adulto del sexo masculino. Rev Cubana Aliment Nutr 1988;12:91-5.

18. Garrido RP, González M. Índices de masa corporaly composición corporal un estudio antropométrico de 2500 deportistas de alto nivel. 2004. http://efdeportes.com/ (accessed Sep 2004).

19. Garn SM, Leonard WR, Hawthorne VM. Three limitations of the body mass index. Am J Clin Nutr 1986;44:996-7.

20. Serrano JM, Shahidian S, Voser RdaC, et al. Incidéncia e fatores de risco de lesões em jogadores de futsal portugueses. Rev Bras Med Esporte 2013;19:123-9.

21. Baroni B, Generosi R, Junior E. Incidence and factors related to ankle sprains in Athletes of futsal national teams. Fisioter Mov 2008;21:79-88.

22. Ekstrand J, Gillquist J. Soccer injuries and their mechanisms: a prospective study. Med Sci Sports Exerc 1983;15:267-70.

23. Abate M, Schiavone $\mathrm{C}$, Salini V. High prevalence of patellar and achilles tendinopathies in futsal athletese. J Sports Sci Med 2012;11:180-1.

24. Kurata DM, Junior JM, Nowotny JN. Incidencia de lesoes em atletas praticantes de futsal. IC Cesumar 2007;9:45-51.

25. Junge A, Dvorak J. Injury risk of playing football in futsal world cups. Br J Sports Med 2010;44:1089-92.

26. Ribeiro RN, Costa LOP. Epidemiologic analysis of injuries occurred during the $15^{\text {th }}$ Brazilian Indoor Soccer (Futsal) Sub20 Team Selection Championship. Rev Bras Med Esporte 2006;12.

27. Hootman JM, Dick R, Agel J. Epidemiology of collegiate injuries for 15 sports: summary and recommendations for injury prevention initiatives. J Athl Train 2007;42:311-9.

28. Cohen M, Abdalla RJ, Ejnisman B, et al. Lesoes ortopédicas no futebol. Rev Bras Ortop 1997;32:940-4.

29. Lindenfeld TN, Schmitt DJ, Hendy MP, et al. Incidence of injury in indoor soccer. Am J Sports Med 1994;22:364-71. 